УДК 621.311.24

DOI https://doi.org/10.32838/2663-5941/2019.4-2/06

\title{
Чернюк А.М.
}

Українська інженерно-педагогічна академія

\section{Кирисов I.Г.}

Українська інженерно-педагогічна академія

Сук I.B.

Київський енергетичний коледж

Карлова О.М.

Київський енергетичний коледж

Білоус I.O.

Київський енергетичний коледж

\section{АНАЛІЗ ТЕХНОЛОГІЧНИХ СХЕМ ГЕНЕРАЦІЇ ЕЛЕКТРОЕНЕРГІЇ АЛЬТЕРНАТИВНИМИ ДЖЕРЕЛАМИ ЕНЕРГІї}

У статті розглянуто технологічні схеми альтернативних джерел енергії. Збільшення частки генерачії електроенергії альтернативними джерелами енергії в загальній структурі генерації в перспективі буде зростати, тому вплив альтернативних джерел енергії на роботу єдиної енергосистеми Украӥни буде збільшуватися. Інтеграчії альтернативних джерел енергії в єдину енергетичну систему Украӥни перешкоджає низка проблем, а саме: графік видачі електроенергії альтернативними джерелами енергії нерівномірний $і$ залежить від кліматичних і погодних умов; велика частина матеріальнотехнічної бази наявних потужностей єдиної енергетичної системи Украйни з виробництва електроенергії зношена і неефективна; якість електроенергії, вироблюваної альтернативними джерелами енергії, не завжди відповідає нормативним вимогам. Нормативні документи встановлюють такі показники якості електричної енергї: усталене відхилення напруги, розмах зміни напруги, доза флікера, коефіиієнт спотворення синусоїдальності кривої напруги, коефіиієнт п-ої гармонійної складової частини напруги, коефіцієнт несиметрії напруг за зворотною послідовністю, коефіиієнт несиметрії напруг за нульової послідовності, відхилення частоти, тривалість провалу напруги, імпульсна напруга, коефіцієнт тимчасової перенапруги. Ці показники мали бути тільки у визначених межах.

Проаналізовано технологічний процес виробництва електроенергії альтернативними джерелами енергії. Проаналізовано переваги та недоліки кожного виду станцій на альтернативних джерелах енергії. Проаналізовано проблеми, що виникають під час інтеграчії альтернативних джерел енергії в єдину енергетичну систему Украӥни.

Ключові слова: електрична енергія, альтернативні джерела енергї, електричні мережі, енергосистема, показники якості електроенергії.

Постановка проблеми. У сучасних умовах велике значення приділяється енергетичній незалежності України. Саме тому нагальним питанням української енергетики є збільшення генерації електричної енергії за рахунок власних енергетичних ресурсів. Нині найбільш динамічно зростає сектор генерації електричної енергії на основі альтернативних джерел енергії (АДЕ) (сонячні електростанції, вітрові електростанції, біогазові, малі ГЕС та інші).

Встановлені потужності АДЕ в Україні мають тенденцію до щорічного зростання. Середньо- річний темп зростання встановленої потужності АДЕ становить $31 \%$. Нині встановлена потужність об'єктів відновлюваної енергетики в Україні дорівнює 1117,7 МВт [7]. Сумарний потенціал встановлених потужностей в Україні оцінюється в 408,2 ГВт: вітрова енергетика - 321 ГВт (78\%), сонячна енергетика - 71 ГВт $(17 \%)$, малі ГЕС 4 ГВт (1\%), біомаса - 15 ГВт (4\%).

Аналіз останніх досліджень і публікацій. До чинників, які сприятимуть розвитку АДЕ у всьому світі та в Україні зокрема, зараховуємо подальше здешевленнятехнологійтавартостіелектростанцій 
на АДЕ. До 2025 р. експерти прогнозують суттєве здешевлення вартості встановлення електростанцій: витрати на встановлення сонячних електростанцій (СЕС) промислового масштабу знизяться за 10 років на $57 \%$, а витрати на встановлення вітрових електростанцій (ВЕС) - на 13\% [7]. Сумарна частка генерації АДЕ у структурі генерації електричної енергії нині становить близько 1,7\% від сумарної генерації єдиною енергосистемою України (таблиці 1, 2; рис. 1).

Відповідно до енергетичної стратегії України до 2035 р. [1] частка генерації електроенергії АДЕ у структурі загальної генерації у 2035 р. станови- тиме $13 \%$, тому проблема, пов'язана з інтеграцією цих джерел до єдиної енергосистеми, є надзвичайно актуальною (таблиця 3 ; рис. 2).

Однак інтеграції АДЕ до єдиної енергосистеми перешкоджає низка проблем:

1) графік видачі електроенергії АДЕ нерівномірний і залежить від кліматичних та погодних умов;

2) більша частина матеріально-технічної бази наявних потужностей із виробництва електроенергії в Україні є зношеною та неефективною. За даними Інституту відновлюваної енергетики НАН України [8], 42,2\% ЛЕП напругою 220-330 кВт

Таблиця 1

Структура генерації електроенергії в Україні різними типами електростанцій

\begin{tabular}{|c|c|c|c|c|c|c|c|}
\hline \multirow{2}{*}{$\begin{array}{c}\text { Виробники } \\
\text { електроенергії }\end{array}$} & $\mathbf{2 0 1 2}$ & $\mathbf{2 0 1 3}$ & $\mathbf{2 0 1 4}$ & $\mathbf{2 0 1 5}$ & $\mathbf{2 0 1 6}$ & $\mathbf{2 0 1 7}$ & $\mathbf{2 0 1 8}$ \\
\hline АЕС & 90138,20 & 83209,00 & 88389,30 & 87627,50 & 80950,10 & 85576,10 & 84398,2 \\
\hline ТЕС & 78908,40 & 78297,80 & 68469,50 & 49386,30 & 49902,30 & 44960,00 & 47791,5 \\
\hline $\begin{array}{c}\text { ТЕЦ, КУ, } \\
\text { блок-станції }\end{array}$ & 17594,20 & 16594,40 & 14690,90 & 12251,80 & 13107,20 & 12412,20 & 12519,8 \\
\hline ГЕС и ГАЕС & 10842,90 & 14216,00 & 9092,60 & 6808,50 & 9297,50 & 10567,70 & 12008,4 \\
\hline $\begin{array}{c}\text { АД (ВЕС, СЕС, } \\
\text { біомаса) }\end{array}$ & 613,20 & 1247,20 & 1771,90 & 1591,10 & 1560,30 & 1898,10 & 2633 \\
\hline РАЗОМ & 198096,90 & 193564,40 & 182414,20 & 157665,20 & 154817,40 & 155414,10 & 159350,9 \\
\hline
\end{tabular}

Структура генерації електроенергії в Україні у відсотках

Таблиця 2 від загального виробництва різними типами електростанцій

\begin{tabular}{|c|c|c|c|c|c|c|c|}
\hline \multirow{2}{*}{ Виробники електроенергії } & \multicolumn{7}{|c|}{ Частка від загального виробництва , \% } \\
\cline { 2 - 9 } & $\mathbf{2 0 1 2}$ & $\mathbf{2 0 1 3}$ & $\mathbf{2 0 1 4}$ & $\mathbf{2 0 1 5}$ & $\mathbf{2 0 1 6}$ & $\mathbf{2 0 1 7}$ & $\mathbf{2 0 1 8}$ \\
\hline АЕС & 45,5 & 43 & 48,4 & 55,6 & 52,3 & 55,1 & 53 \\
\hline ТЕС & 39,9 & 40,5 & 37,5 & 31,3 & 32,2 & 28,9 & 30 \\
\hline ТЕЦ, КУ, блок-станції & 8,8 & 5,6 & 8,1 & 7,8 & 8,5 & 8 & 7,8 \\
\hline ГЕС и ГАЕС & 5,5 & 7,3 & 5 & 4,3 & 6 & 6,8 & 7,5 \\
\hline $\begin{array}{c}\text { Альтернативні джерела } \\
\text { (ВЕС, СЕС, біомаса) }\end{array}$ & 0,3 & 0,6 & 1 & 1 & 1 & 1,2 & 1,7 \\
\hline ЗАГАЛОМ & 100 & 100 & 100 & 100 & 100 & 100 & 100 \\
\hline
\end{tabular}

Таблиця 3

Прогноз генерації електроенергії до 2035 р. згідно з Енергетичною стратегісю України, затвердженою КМУ 18.08 .2017 p.

\begin{tabular}{|c|c|c|c|c|c|}
\hline \multirow{2}{*}{ Виробники електроенергії } & \multicolumn{5}{|c|}{ Виробництво електроенергї, млрд кВт·г } \\
\cline { 2 - 6 } & $\mathbf{2 0 1 5}$ & $\mathbf{2 0 2 0}$ & $\mathbf{2 0 2 5}$ & $\mathbf{2 0 3 0}$ & $\mathbf{2 0 3 5}$ \\
\hline АЕС & 87,6 & 85 & 91 & 93 & 94 \\
\hline ТЕС, ТЕЦ & 61,5 & 60 & 64 & 63 & 63 \\
\hline ГЕС & 6,8 & 10 & 12 & 13 & 13 \\
\hline Альтернативні Джерела (ВЕС, СЕС) & 1,6 & 9 & 12 & 18 & 25 \\
\hline ЗАГАЛОМ & 157,5 & 164 & 178 & 185 & 195 \\
\hline
\end{tabular}


експлуатуються понад 40 років, а $64,4 \%$ основного устаткування трансформаторних підстанцій відпрацювали свій розрахунковий технічний ресурс. У розподільчих мережах значна кількість об'єктів також відпрацювала свій ресурс: 40,5\% електричних мереж і 37,6\% трансформаторних підстанцій потребують реконструкції або заміни;

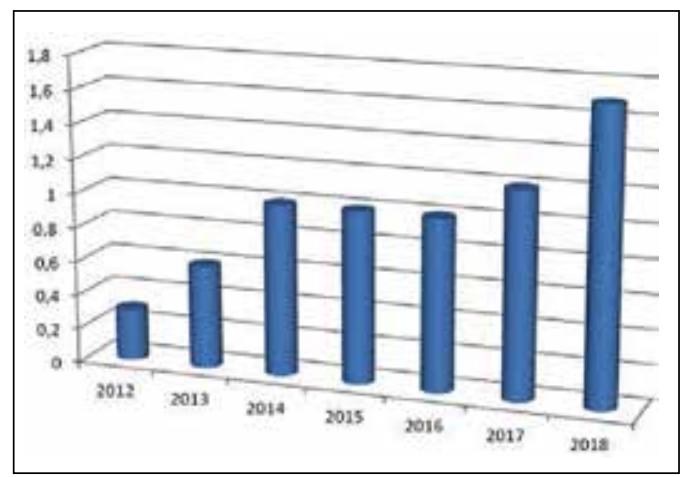

Рис. 1. Зростання частки виробництва електроенергії АДЕ за 2012-2018 р.

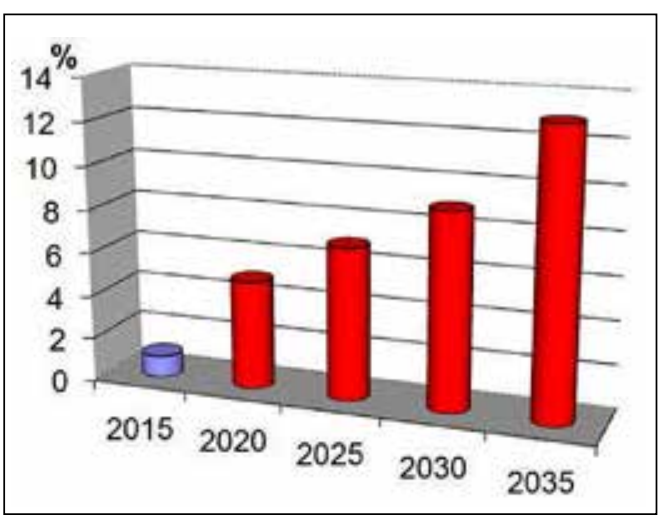

Рис. 2. Зростання частки виробництва електроенергії АДЕ (прогноз до 2035 р.).

3) якість електроенергії, яку виробляють АДЕ, не завжди відповідає нормативним вимогам. Ці вимоги нині зафіксовані в нормативних документах [2].

Стандарт встановлює такі показники якості електричної енергії:

- усталене відхилення напруги $\delta \mathrm{U}_{\mathrm{y}}$;

- розмах зміни напруги $\delta \mathrm{U}_{\mathrm{t}}$;

- доза флікера $\mathrm{P}_{\mathrm{t}}$;

- коефіцієнт спотворення синусоїдальності кривої напруги $\mathrm{K}_{\mathrm{U}}$;

- коефіцієнт n-ої гармонійного складника напруги $\mathrm{K}_{\mathrm{U}(\mathrm{n})}$;

- коефіцієнт несиметрії напруг за зворотною послідовністю $\mathrm{K}_{2 \mathrm{U}}$

- коефіцієнт несиметрії напруг за нульовою послідовністю $\mathrm{K}_{\text {оU }}$;

- відхилення частоти $\Delta \mathrm{f}$;

- тривалість провалу напруги $\Delta \mathrm{t}_{\text {п }}$;
- імпульсна напруга $\mathrm{U}_{\text {імп }}$;

- коефіцієнт тимчасової перенапруги $\mathrm{K}_{\text {пер }}$.

У стандарті [2] встановлюються норми за показниками якості електричної енергії, в разі дотримання яких забезпечується електромагнітна сумісність електричних мереж систем електропостачання загального призначення, в тому числі АДЕ.

Постановка завдання. На сучасному етапі АДЕ $\epsilon$ новим класом генерувальних потужностей із певними особливостями роботи, вплив яких на єдину енергетичну систему України варто оцінити. Актуальність аналізу зумовлена збільшенням частки генерації електричної енергії АДЕ в загальній структурі виробництва електроенергії в Україні. Зі збільшенням цього показника вплив на мережу АДЕ буде зростати. Тому оцінка впливу АДЕ на показники якості електричної енергії мережі $є$ актуальною науково-технічною проблемою. Метою статті $\epsilon$ проведення попереднього аналізу процесів генерації електроенергії АДЕ, їхніх технологічних схем із метою виявлення суттєвих чинників, які можуть впливати на показники якості електричної енергії.

Виклад основного матеріалу дослідження. Проаналізуємо технологічні схеми різних типів АДЕ.

\section{Вітрова енергетика}

Вітроенергетична установка (вітротурбіна) являє собою комплекс взаємопов'язаного обладнання та споруд, призначений для перетворення енергії вітру на інші види енергії (електричну, механічну, теплову та ін.).

Вітроенергетична установка (ВЕУ) складається з таких функціональних частин:

1) первинний перетворювач;

2) електричний генератор первинний перетворювач та електричний генератор утворюють вітроагрегат;

3) опорно-поворотний пристрій;

4) система керування ВЕУ.

Загальний вигляд конструктивного компонування ВЕУ з горизонтальною віссю обертання вітроколеса показаний на рис. 3 .

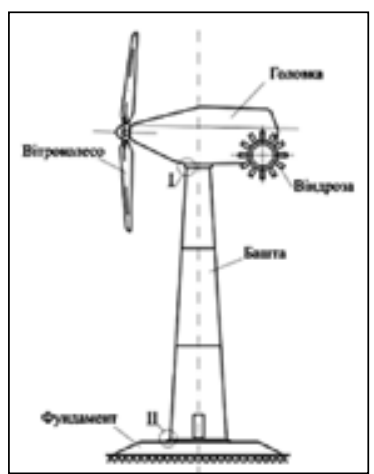

Рис. 3. Конструктивна схема вітроенергетичного агрегату 3 горизонтальною віссю обертання 
Основні функціональні елементи вітрових електроустановок представлені на рис. 4.

Суттєвим недоліком у роботі ВЕУ є їхня нестабільна частота обертання, яка залежить від зміни швидкості вітру. Це питання нині розв'язуються або шляхом системи управління кутом атаки лопатей вітроколеса рис. 5, або шляхом випрямляння та подальшого інвертування отриманої синусоїди. Також є спосіб регулювати частоту обертання шляхом використання автобаласних резисторів.

Структурна схема керування частотою обертання вітроколеса вітроенергетичної установки представлена на рис. 5.

Одна або кілька груп ВЕУ утворюють вітрову електричну станцію (ВЕС), до складу якої входять:

1) вітротурбіна;

2) система керування ВEC;

3) метеовишка;

4) трансформаторні підстанції (ТП);

5) підстанція.

Функціональна схема ВЕС на базі типової вітротурбіни великої потужності представлена на рис. 6.

Система керування ВЕС здійснює керування, контроль та облік роботи ВЕС загалом і кожної ВЕУ окремо. Метеовишка призначена для визначення швидкості й напряму вітру та видачі цієї інформації в систему керування ВЕС. Трансформаторна підстанція обслуговує кілька ВЕУ і забезпечує підвищення напруги від генераторів ВЕУ до величини лінії електропередачі на підстанцію. Підстанція ВЕС призначена для розподілу і передачі енергії від ВЕС в електромережу енергосистеми [3].

Великомасштабне отримання електричної енергії шляхом використання енергії вітру має здійснюватися у вигляді змінної напруги постійної частоти для можливості подачі електроенергії, що виробляється в мережі наявних енергосистем. Можливі технологічні схеми ефективного отримання електричної енергії завдяки енергії вітру при паралельній роботі ВЕУ з енергосистемою представлені на рис. 7.

Зусилля зі створення ВЕУ великої потужності значною мірою пов'язані з використанням вітродвигуна з постійною частотою обертання, сполученого 3 синхронним генератором. Під час використання асинхронного генератора забезпечується обертання вітродвигуна з частотою, близькою до постійної.

Останнім часом привертає увагу інший підхід узгодження роботи ВЕУ з енергосистемою, який полягає в тому, щоб дати змогу вітродвигуну обертатися зі змінною оптимальною частотою, регульованою відповідно до зміни швидкості вітру, із застосуванням спеціальних систем генерації, що забезпечують отримання змінної напруги постійної частоти, яка відповідає частоті напруги енергосистеми.

С багато схем підключення ВЕУ до енергосистеми, основні відмінності яких полягають у конструкції і типі генераторів, а також наявності і типі перетворювальних пристроїв. На рис. 8 показано схеми прямого підключення до енергосистеми ВЕУ із синхронним генератором (рис. 8, $a$ ) i асинхронним рис. 8, б генератором із короткозамкненим ротором, підключені до вітродвигуна через мультиплікатор (редуктор) n. Для реалізації таких схем паралельної роботи ВЕУ 3 мережею енергосистеми необхідною умовою $є$ постійне підтримання синхронної швидкості обертання ротора СГ і надсинхронної швидкості для АГ [3].

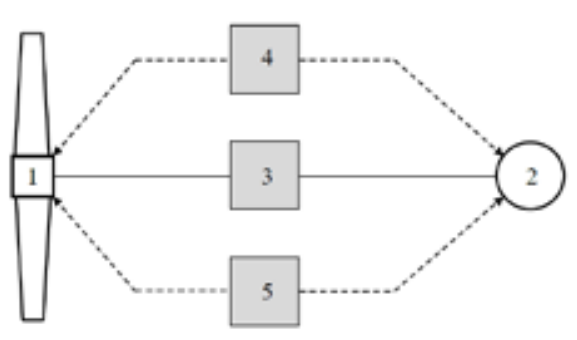

а) функціональна схема

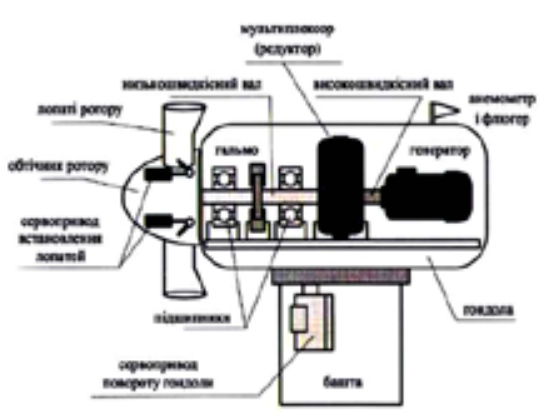

б) розріз

Рис. 4. Основні елементи ВЕУ: 1 - вітровий двигун, 2 - електрогенератор, 3 - механічна передача, 4 - пристрої автоматичного регулювання і керування, 5 - допоміжні пристрої 


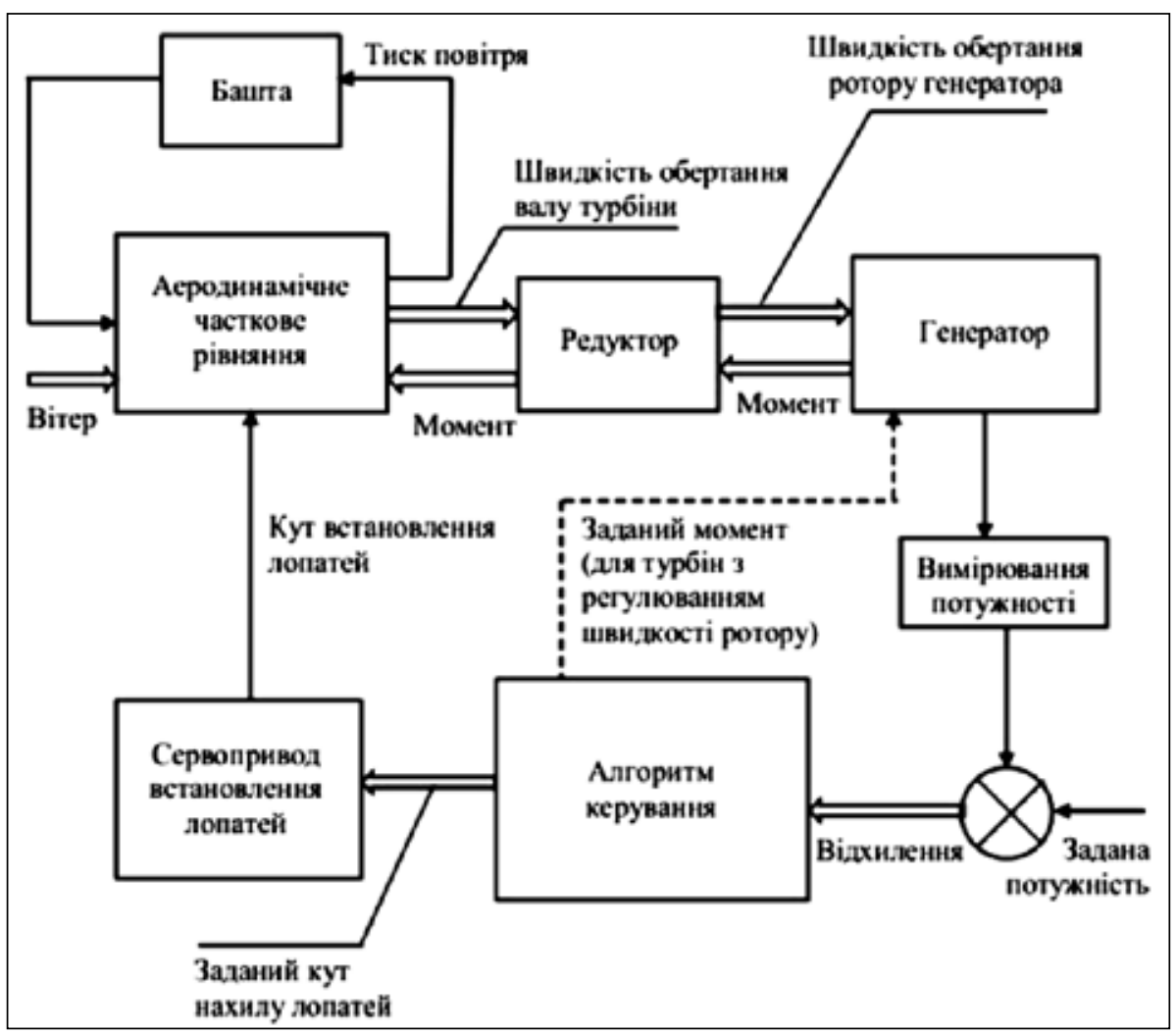

Рис. 5. Загальна структурна схема управління частотою обертання вітроколеса ВЕУ

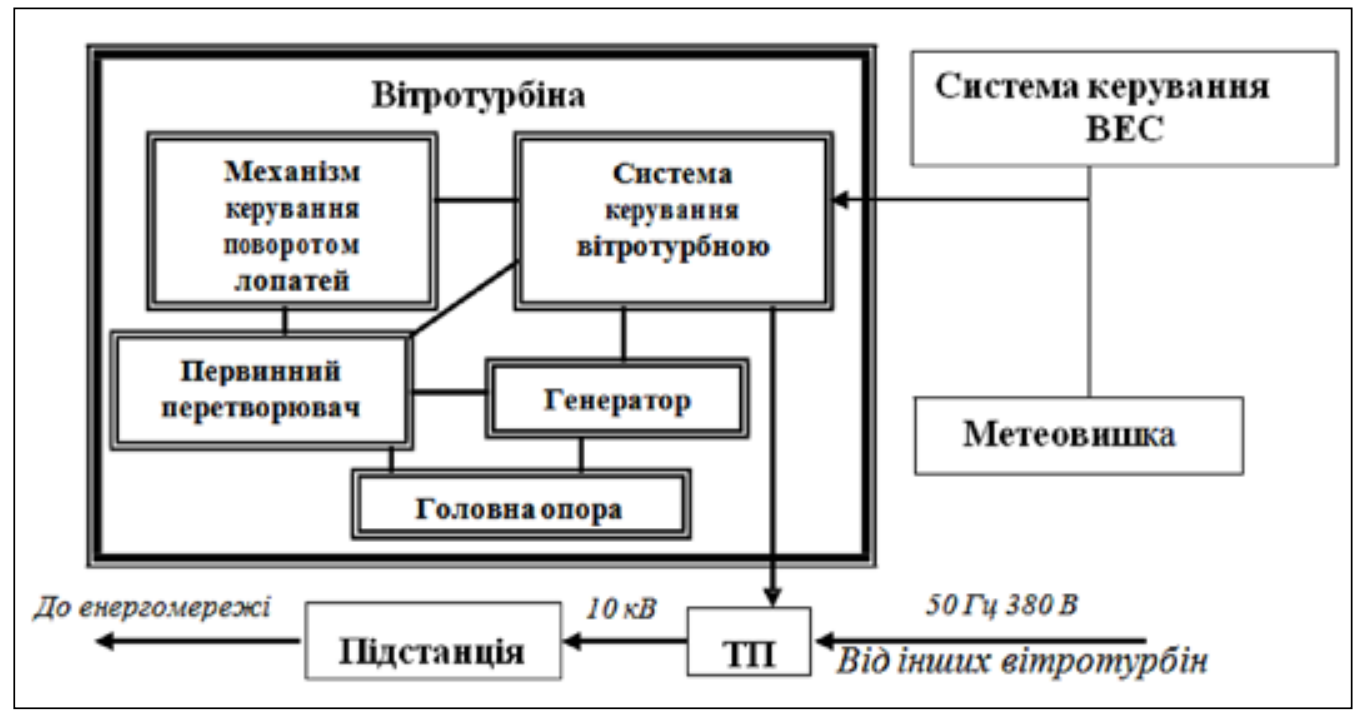

Рис. 6. Функціональна схема ВЕС

На рис. 9, а зображена схема підключення на паралельну роботу з енергосистемою ВЕУ з синхронним генератором. У цій схемі на виході генератора частота струму змінюється в широкому діапазоні відповідно до зміни швидкості вітродвигуна. Далі змінний струм за допомогою випрямляча перетворюється на постійний і двожильним кабелем подається на інвертор, що знаходиться внизу в башті ВЕУ, де й перетворюється на змінний струм частотою 50 Гц. Тип інвертора, який використовується, ведений мережею. При цьому частота на виході інвертора задається фактично наявною в кожну мить частотою мережі. За допомогою інвертора можна міняти кут між струмом i напругою. Якщо струм відстає від напруги, то генератор споживає реактивну потужність, а якщо 

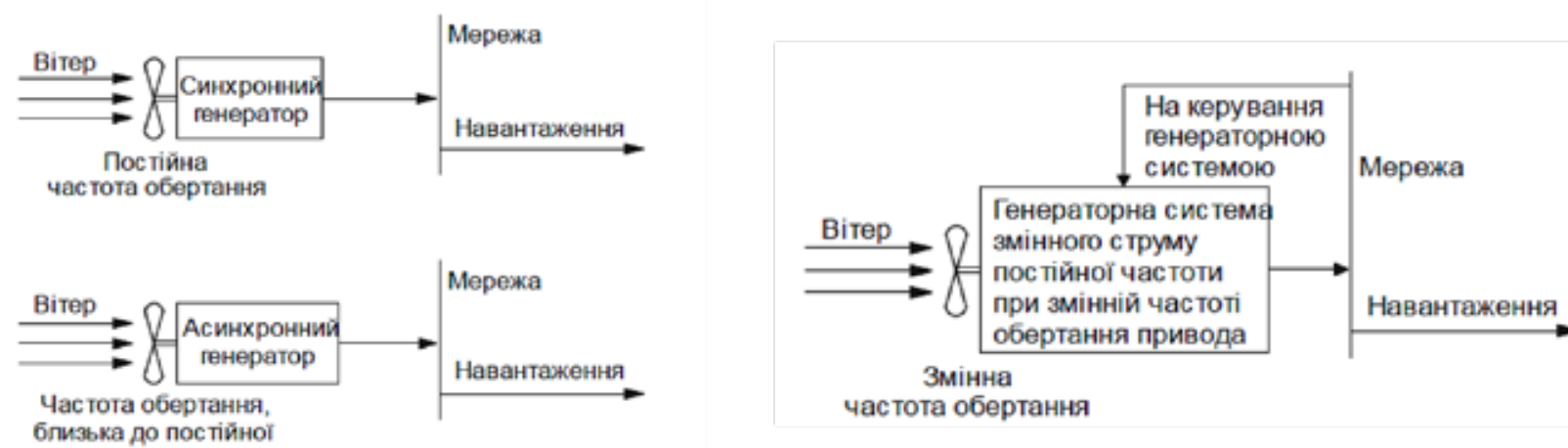

Рис. 7. Структурні схеми систем генерування і використання електроенергії при підключенні ВЕУ до мережі

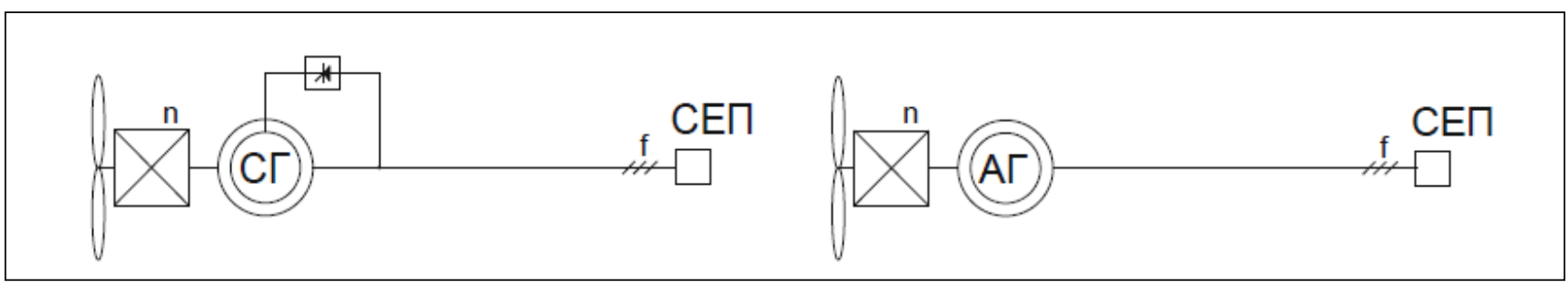

a

Рис. 8. Безпосереднє підключення ВЕУ із синхронним (а) та асинхронним (б) генератором

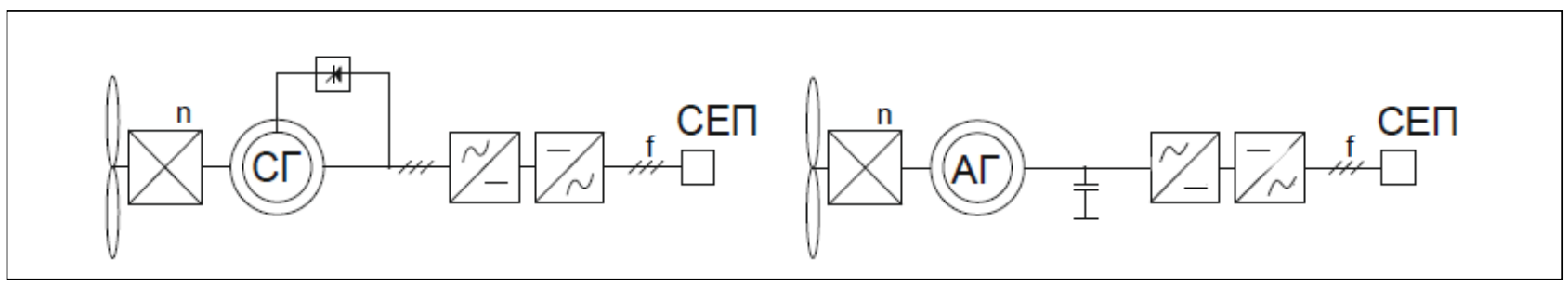

a

6

Рис. 9. Підключення ВЕУ до мережі через випрямляч та інвертор із синхронним (а) та асинхронним (б) генератором

струм випереджає напругу, то генератор виробляє поряд 3 активною й реактивну потужність. Таким чином, вітроустановка може брати участь у регулюванні напруги мережі в точці приєднання ВЕУ до енергосистеми.

На рис. 9, 6 зображена схема підключення на паралельну роботу з енергосистемою ВЕУ з асинХронним генератором із коротко замкненим ротором. Швидкість вітродвигуна і частота струму на виході асинхронного генератора також змінюються в широкому діапазоні, а подальше перетворення i видача вироблюваної ВЕУ електроенергії в енергосистему здійснюється так само, як у схемі рис. 9 а. Оскільки синхронний генератор для намагнічування ротора має споживати реактивну потужність і за рахунок послідовно включених випрямляча та інвертора, не може отримати іiї з мережі, у схему на вихід генератора включена конденсаторна батарея як джерело реактивної потужності [3].

\section{Сонячна енергетика}

Пряме перетворення сонячної енергії на електроенергію за допомогою сонячних батарей $\epsilon$ нині одним із найбільш динамічних напрямів розвитку відновлюваної енергетики. У цьому розвитку істотно сприяє отриманий позитивний досвід практичного застосування сонячних батарей i постійне вдосконалення технологій виготовлення сонячних елементів, пов'язаних із підвищенням їх ККД і зниженням собівартості.

Потужність сонячних батарей, які нині випускаються промисловістю, становить 50-250 Вт. На сонячних електростанціях (CEC) сонячні батареї з'єднуються у фотоелектричні генератори, які працюють паралельно 3 мережею, використовуються для промислового вироблення електроенергії. На рис. 10 представлена структурна схема СEC, яка працює паралельно 3 мережею. 
У СЕС, що працюють паралельно з мережею задля перетворення постійного струму, який виробляється сонячною батареєю, у змінний струм синусоїдальної форми необхідний інвертор. Основними технічними характеристиками інвертора $є$ величина напруги на вході і виході, вихідна частота і потужність. Якісний інвертор має забезпечувати високий ККД і стабілізацію вихідної напруги, низький коефіцієнт гармонік i здатність витримувати можливі перевантаження.

На рис. 11 представлена схема підключення інвертора Fronius до шин низької напруги трансформатора ТМ-1000 сонячної електростанції [4].

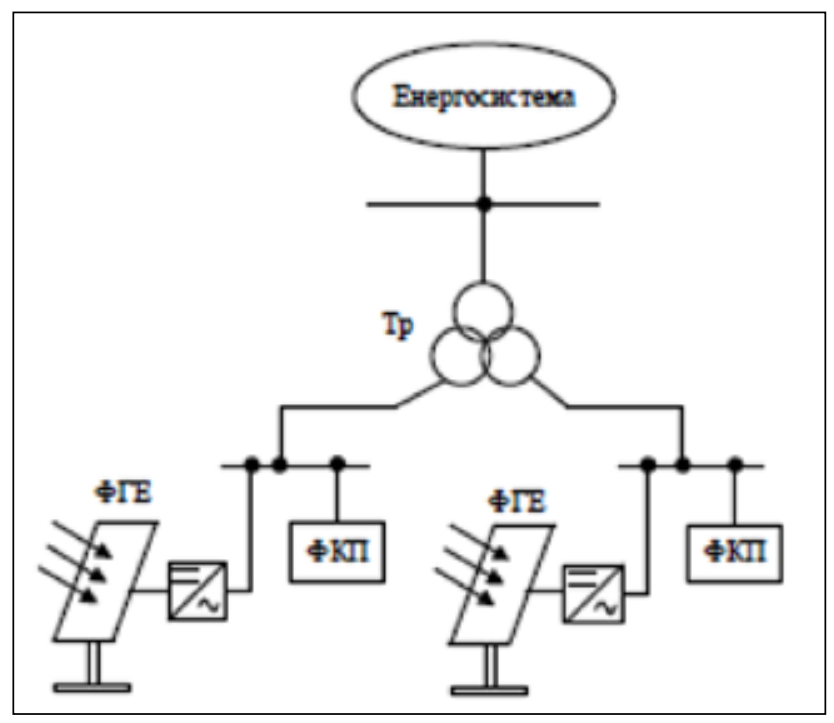

Рис. 10. Структурна схема СЕC

Перевагами СЕС є: безшумність, невичерпність джерела енергії, відсутність деталей, що обертаються, простота та швидкість встановлення, обслуговування, заміни, розширення (збільшення сонячних батарей), простота догляду, строк експлуатації станції 20-30 років.

Недоліками СЕС є: велика вартість сонячних батарей, відчуження великих земельних ділянок, які можуть використовуватися у сільському господарстві, присутність ланки випрямляч-інвертор призводить до спотворення форми синусоїди, робота СЕС без акумуляторних батарей безпосередньо на мережу може створювати небаланс виробленої та спожитої енергії та відхилення напруги.

Біогаз

Біогаз складається 3 метану (55-85\%) та має теплоту згоряння 5340-6230 ккал/кг (6,217,24 кВт·год/кг) та може використовуватися: як

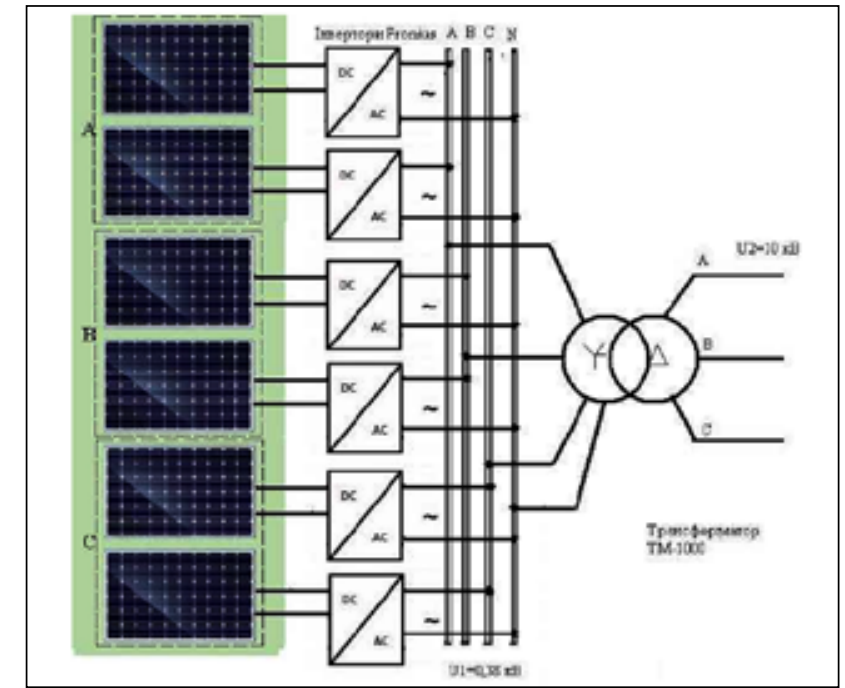

Рис. 11. Принципова схема підключення інвертора Fronius СЕС до шин низької напруги трансформатора ТM-1000

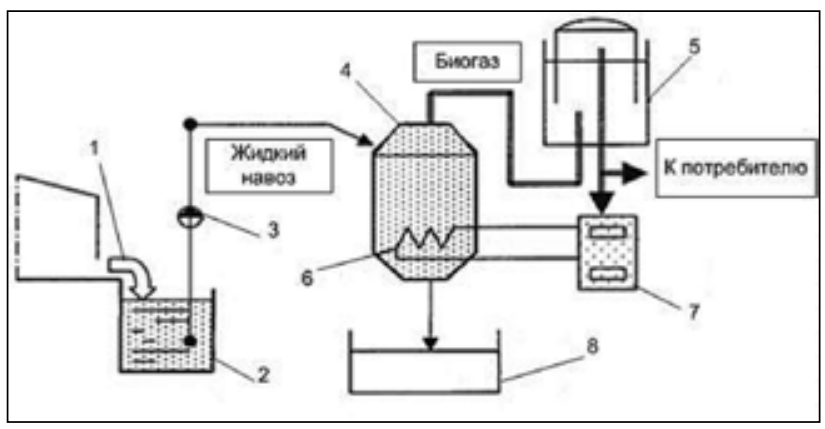

Рис. 12. Схема біогазової установки: 1 - ферма;

2 - резервуар для зберігання гною; 3 - насос; 4 - метантанк; 5 - газгольдер; 6 - теплообмінник; 7 - котел; 8 - сховище добрива

паливо для газогенераторів та газотурбін, для вироблення у подальшому електроенергії чи тепла.

Нині переробка біомаси у паливо здійснюється за трьома напрямами:

1) біоковерсія - розкладення органічних речовин рослинного та тваринного походження без доступу повітря окремими видами бактерій (у спеціальних баках) з утворенням біогазу. При переробці 1 т гною великої рогатої худоби і свиней (з вологістю 85\%) можна отримати від 45 до $60 \mathrm{~m}^{3}$ біогазу, 31 т курячого посліду (з вологістю $75 \%$ ) можна отримати до 100 м3 біогазу. За теплотою згоряння $1 \mathrm{~m}^{3}$ біогазу еквівалентний: $0,8 \mathrm{~m}^{3}$ природного газу, 0,7 кг мазуту або 1,5 кг дров;

2) термохімічна конверсія (деревини, торфу та вугілля) - нагрівання у камері з контрольованою подачею повітря. При цьому утворюються азот (50-54\%), оксид вуглецю (20-22\%), водень 
(12-15\%), двоокис вуглецю (9-12\%), метан. Паливо на газ перетворюється у результаті хімічних процесів висушування, піролізу, спалювання (окислення), відновлення;

3) спалювання відходів (макуха, щепа та інше) в котлах спеціальної конструкції [5].

На рис. 12 показана технологічна схема отримання біогазу з відходів тваринництва.

У процесі переробки усіх відходів рослинного та тваринного походження сільського господарства України можна отримати біля 3,5 млрд м ${ }^{3}$ метану.

\section{Малі ГЕС}

Мала гідроенергетика, яка $є$ найбільш освоєною 3 нетрадиційних відновлювальних джерел електроенергії, дає змогу використати значний гідроенергетичний потенціал малих рік і приток, систем водопостачання, іригації з видачею електроенергії в енергосистему, а в багатьох випадках забезпечити локальне електропостачання віддалених районів або населених пунктів, особливо в недостатньо розвинених країнах і в країнах, що розвиваються, 3 обмеженою системою централізованого електропостачання.

До об'єктів малої гідроенергетики належать малі ГЕС потужністю до $30 \mathrm{MB}$, міні-ГЕС - від 0,1 до 1,0 МВт, мікро-ГЕС - не більше 0,1 МВт.

До переваг малих ГЕС належать порівняно невеликий об'єм інвестицій і короткий термін будівництва, що дає змогу прискорити отримання прибутку, забезпечити мінімальну дію на довкілля, надійність і близькість до споживача.

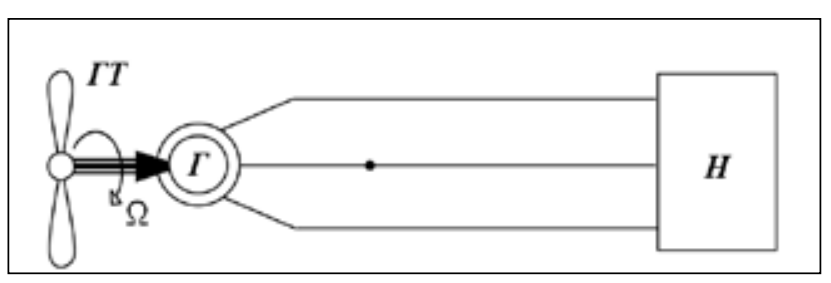

Рис. 13. Структурна схема малої ГЕС:

ГТ - гідротурбіна , Г - генератор, $\mathrm{H}$ - навантаження

\section{Геотермальна енергетика}

Геотермальна енергія - енергія тепла, що виділяється із внутрішніх зон Землі. Головними перевагами геотермальної енергії $є$ ії практична невичерпність і повна незалежність від умов навколишнього середовища, часу доби і року.

Електростанції, на яких виробляється перетворення теплової енергії термальних вод на електроенергію, отримали назву геотермальних теплових електростанцій (ГеоТЕС).

Геотермальні родовища поділяються на чотири основних типи:

- родовища сухої пари,

- родовища вологої пари;

- родовища гарячої води;

- родовища нагрітих сухих порід.

Україна має значні ресурси геотермальної енергії, потенційні запаси якої оцінюються у $10^{22}$ Дж. Потенційна потужність ГеоТЕС в Україні з урахуванням видобутку запасів та ККД перетворення енергії становить 230 ГВт. Пріоритетними районами, де доцільно будувати ГеоТЕС, $є$ Прикарпаття, окремі райони Харківської, Полтавської та Донецької областей [5].

Розрізняють дві основні технологічні схеми ГеоТЕС: прямим використанням енергії пари та непрямим використанням пари.

Основними недоліками ГеоТЕС $є$ теплове, сольове, газове забруднення навколишнього середовища.

Висновки. Збільшення частки генерації електроенергії АДЕ у структурі генерації України в перспективі буде зростати, а отже, вплив цих джерел живлення на роботу єдиної енергосистеми буде лише збільшуватися.

Значний вплив на сукупну генерацію електроенергії АДЕ зумовлює актуальну науково-технічну проблему інтеграції АДЕ до єдиної енергосистеми та суміщення графіків генерації і споживання.

Особливості процесу генерації електроенергії АДЕ, які проаналізовані у статті, безпосередньо зумовлюють їх вплив на баланс та показники якості електроенергії.

\section{Список літератури:}

1. Енергетична стратегія України на період до 2035 року «Безпека, енергоефективність, конкурентоспроможність». URL: https://zakon.rada.gov.ua/laws/show/605-2017-\%D1\%80

2. ГОСТ 13109-97. Электрическая энергия. Совместимость техническая электромагнитная. Нормы качества электрической энергии в системах электроснабжения общего назначения. Межгосударственный стандарт.

3. Нойбергер Н., Ципленков Д., Півняк Г., Шкрабець Ф., Основи вітроенергетики : підручник. Дніпропетровськ : НГУ. 2015. С. 275-290.

4. Бацала Я.В., Гладь І.В., Николин У.М., Аналіз показників якості електроенергії сонячної електростанції. Розвідка та розробка нафтових і газових родовищ. 2013. № 4(49). С. 81-90.

5. Обухов С.Г. Системы генерирования электрической энергии с использованием возобновляемых энергоресурсов : Учебное пособие. Томск. 2008. С. 130-132. 
6.Зысин Л.В., Сергеев В.В. Нетрадиционные и возобновляемые источ-ники энергии. Часть 1. Возобновляемые источники энергии : Учеб. пособие. Санкт-Петербург : Изд-во Политехн. ун-та, 2008. C. $160-169$.

7. Розвиток відновлюваних джерел енергії в Україні. Звіт 2017.

8. Сайт інституту відновлювальної енергетики. URL: http://www.ive.org.ua/

\section{Chernyuk A.M., Kirisov I.G., Suk I.V., Karlova E.N., Belous I.A. ANALYSIS OF TECHNOLOGICAL SCHEMES OF ELECTRIC ENERGY GENERATION BY ALTERNATIVE ENERGY SOURCES}

The article discusses the technological schemes of alternative energy sources. The increase in the share of electricity generation by alternative energy sources in the overall structure of generation will increase in the future, therefore, the influence of alternative energy sources on the operation of the unified energy system of Ukraine will increase. The integration of alternative energy sources into a single energy system of Ukraine is hampered by a number of problems, namely: the schedule for the delivery of electricity by alternative energy sources is uneven and depends on climatic and weather conditions; most of the material and technical base of the existing capacity of the unified energy system of Ukraine for the production of electricity is worn out and inefficient; The quality of electricity generated by alternative energy sources does not always meet regulatory requirements. Regulatory documents establish the following indicators of the quality of electrical energy: steady-state voltage deviation, voltage swing, flicker dose, voltage curve sinusoidal distortion factor, voltage $n$-th harmonic component, reverse sequence voltage unbalance factor, zero-sequence voltage unbalance factor, frequency deviation, duration of voltage dip, pulse voltage, coefficient of temporary overvoltage of life. These indicators should be within strictly defined limits.

Analyzed the technological process of electricity production by alternative energy sources. The advantages and disadvantages of each type of station on alternative energy sources are analyzed. The problems arising from the integration of alternative energy sources into a single energy system of Ukraine are analyzed.

Key words: electrical energy, alternative energy sources, electrical networks, power system, power quality indicators. 